\title{
A homlokmarási technológia hőkamerás elemzése a fordulatszám változtatása mellett
}

\section{Analysis of face milling technology with a thermal camera by the changing of the number of revolution}

\author{
D. PREZENSZKI ${ }^{1}$, Cs. WESSER ${ }^{2}$, S. BODZÁS ${ }^{3}$ \\ ${ }^{1}$ Debreceni Egyetem, Múszaki Kar, Gépészmérnöki Tanszék, dorottya96@gmail.com \\ ${ }^{2}$ Grimas kft., csaba.wesser@grimas.hu \\ ${ }^{3}$ Debreceni Egyetem, Műszaki Kar, Gépészmérnöki Tanszék, bodzassandor@eng.unideb.hu
}

Absztrakt. A publikáció célkitüzése homlokmarási technológia során a forgácsleválasztáskor képzôdő hőmérsékleti zóna vizsgálata hôkamerával. A vizsgálatot diszkrét fordulatszám értékek változtatásával a többi technológiai paraméter állandóssága mellett végezzük el. Megtervezzük a mérési koncepciót. A kísérletek elvégezte után elemezzük a kapott höképeket.

Abstract. The aim of the publication is the analysis of the temperature zone of cutting operation in case of face milling technology. The analyses are done considering of the changing of discreet number of revolution beside the constancy of the more technological parameters. The measuring concept will be determined. After the experiments the received thermal images will be analysed.

\section{Bevezetés}

A kutatási tevékenységünk során a homlokmarási technológiát vizsgáljuk egy modern hőkamera segítségével a fordulatszám változtatása mellett.

Célkitűzésünk a kialakult hőmérséklet eloszlási képek elemzése az alkalmazott technológiai paraméterek függvényében.

Leírjuk a felvételeink elkészítésének körülményeit és a technológiai paraméterek megválasztásának menetét.

Ezek után rátérünk a felvételek konkrét kiértékelésére. 


\section{A hőkamerás mérés végrehajtása}

A felvételek elkészítésével kapcsolatosan az alap koncepciónk az volt, hogy mindenfajta hűtési technológia nélkül valósuljanak meg, valamint legyenek állandó és változó technológiai paraméterek is [1].

A használt marólapka egy CWP21 típusú, egyszerűbb kivitelű lapka volt, amelyet a WNT Magyarország kft. forgalmaz [1,2].

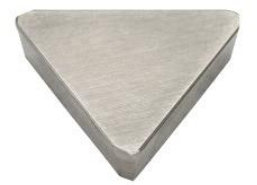

\section{1. ábra: CWP21 típusú marólapka [1,2]}

A forgácsolási adatok megválasztása során a célunk az volt, hogy a változtatott technológiai paraméter a szerszám fordulatszáma legyen. A többi forgácsolási adat állandó volt, tehát nem változtattuk a felvételek elkészítésekor [1].

A használt fordulatszám sor felállításához figyelembe kellett vennünk a gyártó által ajánlott forgácsolási adatokat. Az ajánlott forgácsolási sebességekből tudtunk fordulatszámot számítani és felállítani a fordulatszám sort. A használt képleteket és a kapott eredményeket az 1. táblázat tartalmazza. A számítás úgy történt, hogy a gyártó által ajánlott forgácsolási sebesség sort $10 \mathrm{~m} / \mathrm{min}$ sebességenként felosztottuk és azokból számítottuk át a fordulatszámot (60, 70, 80...160) [1].

\begin{tabular}{|l|c|}
\hline \multicolumn{1}{|c|}{ CWP21 lapka adatai: } & A használt fordulatszám értékek: [1/min] \\
\hline Gyártói ajánlás: $\mathrm{vc}=60-160 \mathrm{~m} / \mathrm{min}$ & $n_{1}=180$ \\
$\mathrm{vc}=\mathrm{n} \times \mathrm{d} \times \pi$ amelyből $\underline{\mathrm{n}=\mathrm{vc} / \mathrm{d} \pi}$ & $n_{2}=224$ \\
ahol vc: a forgácsolási sebesség & $n_{3}=280$ \\
$\quad$ n: a fordulatszám & $n_{4}=355$ \\
d: a marófej átmérője & $n_{5}=450$ \\
\hline
\end{tabular}

1. táblázat: A használt fordulatszám értékek számításának módja [1]

Ahogy már korábban említettük, a többi forgácsolási paramétert állandóként kezeltük. A 2. táblázat tartalmazza az állandó paramétereket. Ezen értékek megválasztásakor szintén figyelembe vettük a gyártó által ajánlott adatokat, valamint Géresi Zoltán Gergő CNC technológus javaslatát is.

\begin{tabular}{|l|l|}
\hline & $v_{f}=63 \mathrm{~mm} / \mathrm{min} \quad v_{f}=$ előtoló sebesség \\
& $f_{z}=0,08 \mathrm{~mm} \quad f_{z}=$ fogankénti előtolás \\
& $a=0,25 \mathrm{~mm} \quad a=$ fogásmélység \\
\hline
\end{tabular}

2. táblázat: Az állandó paraméterek a felvételek készítése közben [1]

Ezen kiértékelés alkalmával csak a minimális (180 $1 / \mathrm{min})$ és a maximális (450 $1 / \mathrm{min})$ fordulatszámokról készült felvételeket elemeztük ki [1].

A felvételek elkészítését a GRIMAS kft. támogatta. Wesser Csaba, a cég egyik termográfus szakembere jött el hozzánk és hozta el magával a hőkamerát. A használt kamera egy FLIR T1020 típusú kamera volt [1]. 


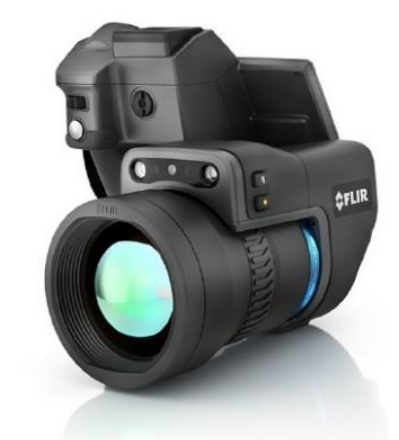

2. ábra: A használt hökamera [1,3]

A 3. ábrán a mérési beállás látható. A szerszámgép bal oldaláról lettek elkészítve a felvételek.

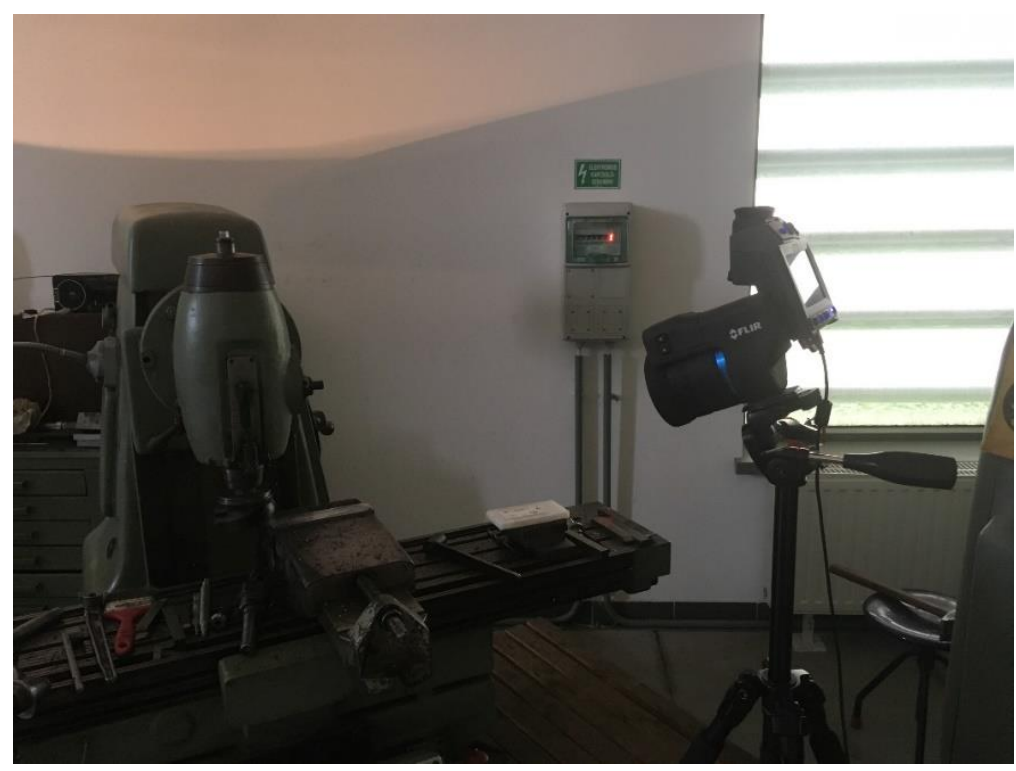

3. ábra: A mérési beállás [1]

\section{A kapott hővideók és képek kiértékelése}

A kapott felvételeket a Grimas kft.-től kapott Flir Tools nevű program segítségével értékeltük ki. Ez a szoftver mérőcellákat alkalmaz a hőmérsékletek megállapításához. Különböző alakú mérőcellákat tudunk használni. Mi az ellipszis alakú mérőeszközt alkalmaztuk a kiértékelések során. A program a kiválasztott és a megfelelő helyre tett cellán belül képes megmutatni a minimális, maximális és átlag hőmérsékletet. A maximális piros, míg a minimális hőmérsékletet kék színű nyílfejjel jelzi ki számunkra [1]

A felvételek kiértékelése során kizárólag a közvetlen forgácsleválasztási zónára fókuszáltunk. Ez azt jelenti, hogy csak azokat a mért maximális hőmérsékleteket vettük figyelembe, amelyek ebben a zónában fordultak elő [1].

A kiértékelés folyamata úgy nézett ki, hogy mivel a kapott videók hossza azonos volt, így fel tudtuk osztani a videókat egyenlően 10 másodpercenként. Ez pontosan azt jelenti, hogy 10 másodpercet 
dolgozott a gép és a 10. másodperc előtti és utáni másodpercben vizsgáltuk a hőmérsékleti értékeket képkockánként és választottuk ki a legmagasabb értéket a forgácsleválasztási zónából [1].

A kiértékelés során kapott adatokat a 4. ábra diagramos formában szemlélteti.

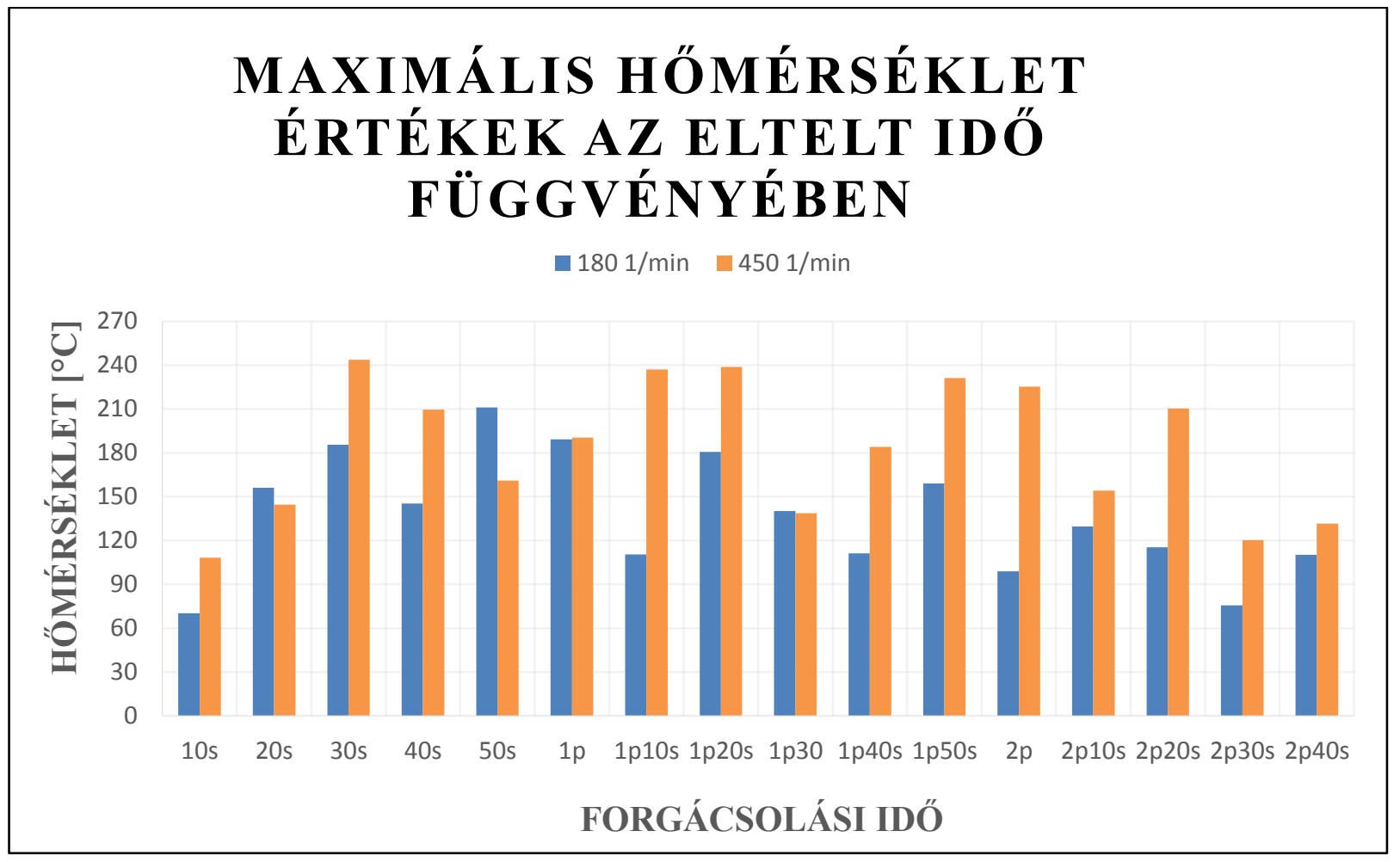

4. ábra: A kapott eredmények [1]

A kezdő, $10 \mathrm{~s}$ időpillanathoz tartozó hőmérsékleti értéket akkor mértük, amikor a marólapka éppen belekapott a munkadarab felületébe. Már ezek az értékek is magasnak tekinthetőek, köszönhetően annak, hogy nem használtunk semmilyen felülethütési technikát [1]

A 4. ábra jól szemlélteti, hogy a narancssárgával jelzett maximális fordulatszámon keletkezett hőmérsékletek a legtöbb esetben meghaladják a kék színnel jelzett legalacsonyabb hőmérsékleti értékeket. Természetesen ez volt az az eredmény, amelyre számítottunk, hiszen a fizika törvényei is ezt támasztják alá [1].

Számítottunk mindkét esetre vonatkozóan átlag hőmérsékleteket. A legnagyobb fordulatszám érték esetében $183^{\circ} \mathrm{C}$, míg a legalacsonyabb fordulatszám esetében $137^{\circ} \mathrm{C}$. Ez a két szám is mutatja az eredményt. Tehát a magasabb fordulatszám esetén lényegesen nagyobb hőmérsékleti átlag érték volt mérhető, mint a legkisebb fordulatszám esetén [1]. 
International Journal of Engineering and Management Sciences (IJEMS) Vol. 4. (2019). No. 4 DOI: 10.21791/IJEMS.2019.4.15.
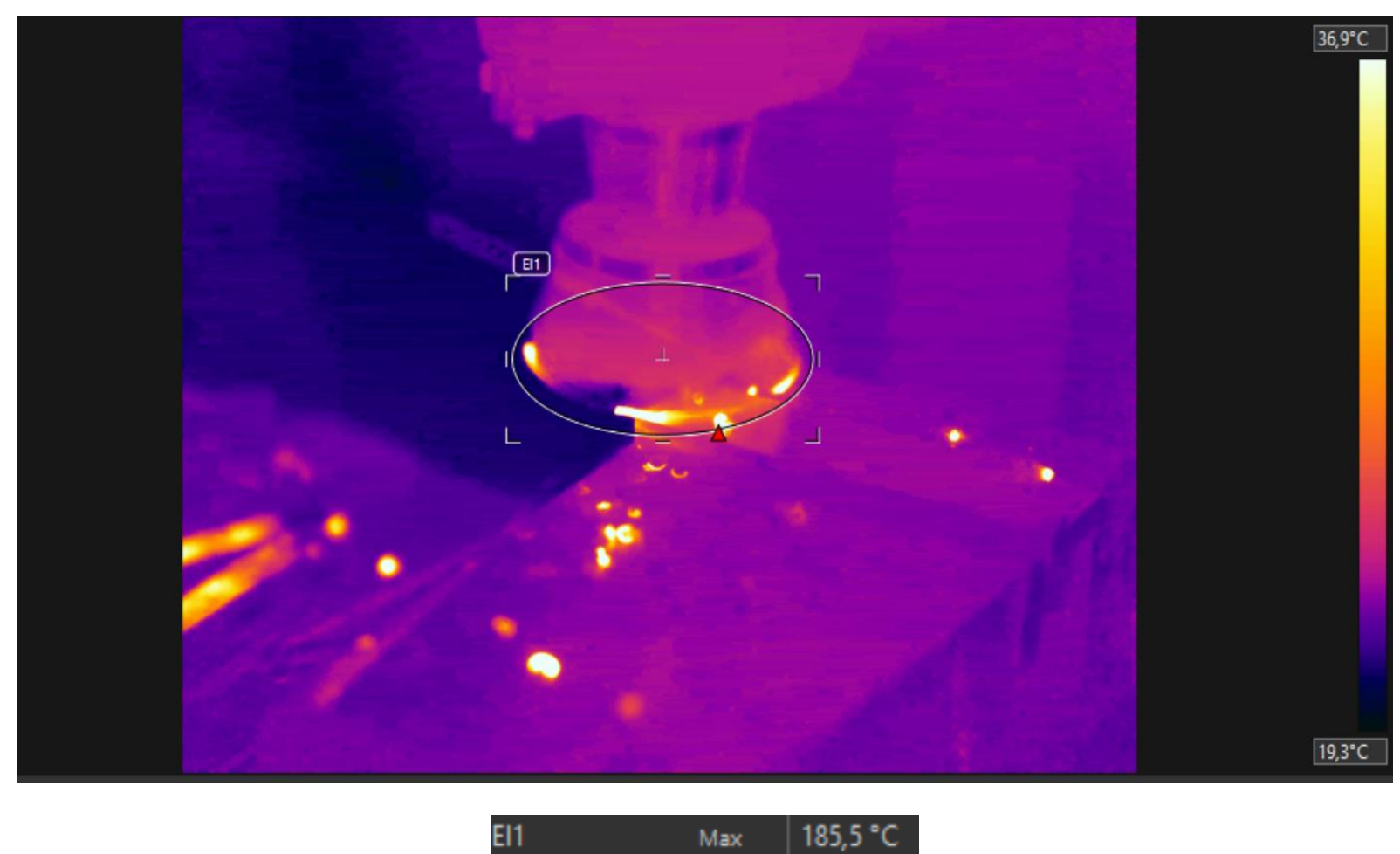

5. ábra: 180 1/min fordulatszámon mért maximális hőmérséklet 30 s után [1]

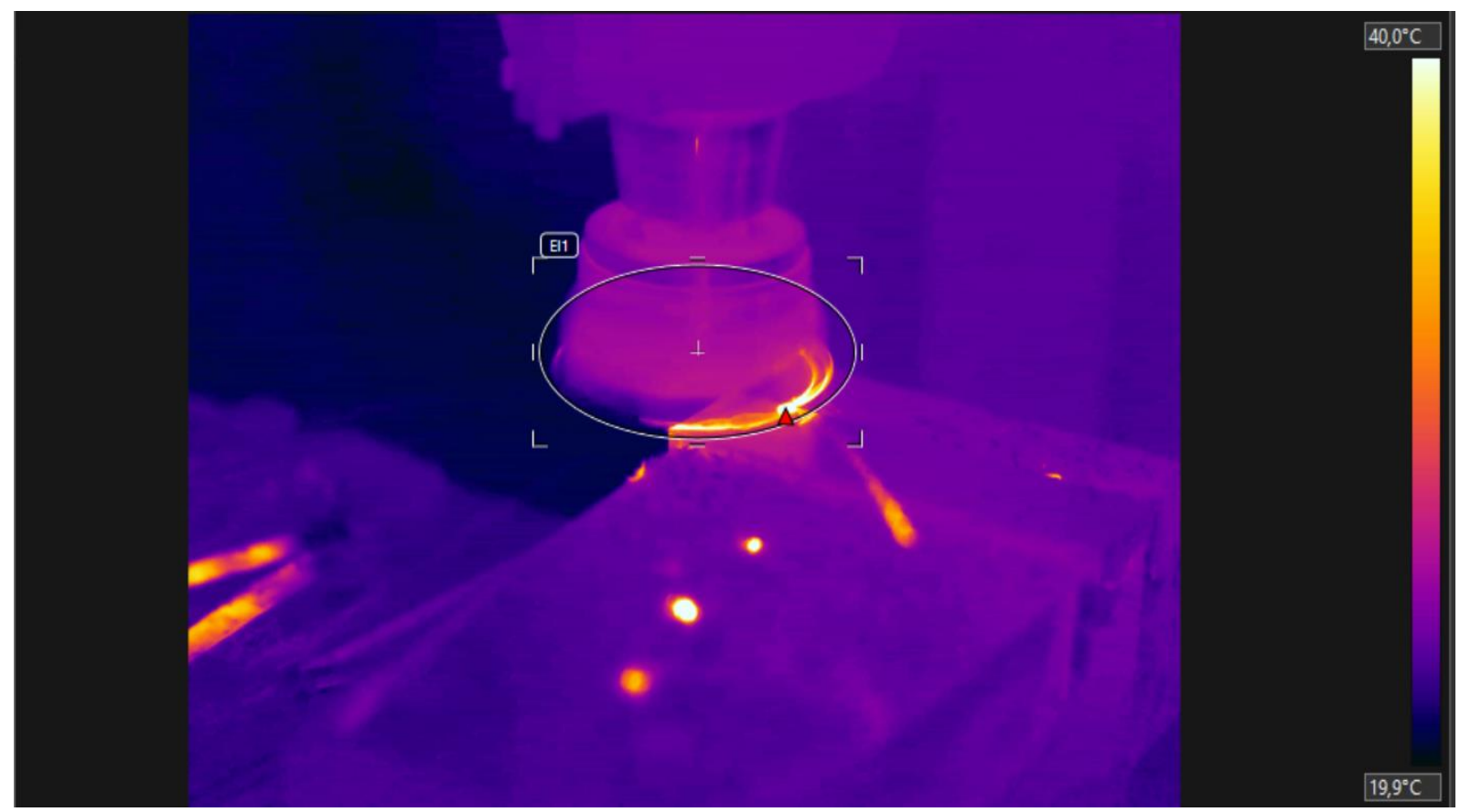

El1 $\quad \operatorname{Max} \quad 243,8^{\circ} \mathrm{C}$

6. ábra: 450 1/min fordulatszámon mért maximális hőmérséklet 30 s forgácsolás után [1] 


\section{Összefoglalás}

A kutatás során a homlokmarási technológiát vizsgáltuk egy modern hőkamera segítségével a fordulatszám változtatása mellett.

Elkészítettük a hőkamerás felvételeket a Debreceni Egyetem Műszaki Karának forgácsoló laborjában. A technológiai paraméterek közül csak a marószerszám fordulatszámát változtattuk, a többi adat állandó maradt.

A Flir Tools kiértékelő szoftver segítségével kiértékeltük a kapott felvételeket.

A célunk az volt, hogy bebizonyítsuk, a forgácsleválasztási zónában keletkezett hőmérséklet a maximális fordulatszámon magasabb, mint a legkisebb fordulatszámon mért hőmérsékleti értékek.

A továbbiakban tovább szeretnénk foglalkozni a témával, más koncepciójú felvételek késztését is tervezzük.

\section{Köszönetnyílvánítás}

A publikáció elkészítését az EFOP-3.6.1-16-2016-00022 számú projekt támogatta. A projekt az Európai Unió támogatásával, az Európai Szociális Alap társfinanszírozásával valósult meg.

\section{Hivatkozások}

[1] D. Prezenszki (2019) Homlokmarási technológia hőkamerás elemzése a fordulatszám változtatásával, TDK dolgozat, Debreceni Egyetem Műszaki Kar (konzulens: Bodzás S.)

[2] WNT Ceratizit Group: Szerszámkatalógus https://www.wnt.com/hu.html

[3] FLIR SYSTEMS: Felhasználói kézikönyv FLIR T10xx sorozat, 2018, Publ. No.:T559954, 310p 